\title{
THE SYMBOLS AND STEREOTYPES OF SIBERIA FOR ESTONIANS AND THEIR HISTORICAL BACKGROUND
}

\author{
Aivar Jürgenson
}

\begin{abstract}
Siberia has traditionally been associated with cold, darkness, prisons, and wild nature. Siberia has a negative connotation for Estonians, Latvians and Lithuanians, especially because of Soviet deportations carried out in the 1940s. However, by that time Siberia had already been used as a prison for several centuries. It is mainly for these reasons that the image of Siberia has been negative. Yet, it can also be positive; for example, for those who were born and bred in Siberia and for whom Siberia is homeland. This article analyses the symbols and stereotypes of Siberia for Estonians and their historical background.
\end{abstract}

Keywords: diaspora, image, Siberia, stereotypes, symbols, voluntary and forced migration

A young Estonian man, who had fled from Estonia during the Second World War and had settled in Canada, described his first years in his new abode:

For a longer period already, having lived in this capital of Estonians, together with my family under my own roof, working only five days a week and bringing home a satisfactorily bulky envelope with salary, everything feels so contrastively different to what it was like then, two to three years ago. It is amazing to think that I was here in the very same Canada, which felt like Siberia rather than Mecca for refugees and other immigrants. (Parts 1954: 9)

We do not know what that young man had in mind when he compared Canada with Siberia. Was it the fact that both have a continental climate, cold and snowy winters? One could speculate so, but probably there are also other grounds for comparison. Siberia here is projected as a metaphoric contrast to Mecca - a place that for a Muslim represents the main destination of their earthly wanderings, the destination of their pilgrimage. In the present context, Siberia should symbolise a place that one should rather avoid.

The collection of articles published in Irkutsk in 1987 contains writings by Western journalists and essayists and as such sheds light on the West- 
European and American contemporary imagination of Siberia. A stereotypical picture prevails: a vast land where distance separates people and where isolation has affected people's mental state (Smitt 1987: 104), a wild country with impenetrable forests and blizzardy tundra inhabited in most part by wolf packs (Mowat 1987: 65), Siberia as a destination for deportations (Griffin 1987: 93).

Siberia - for the people in the Baltic countries it is first and foremost a land of barbed wire, and for us the deportations of the 1940s have branded a burning image on the part of the world where Siberia is situated. And nothing shows from underneath that image, even if there was something there previously. Deportations, cattle wagons, anonymous graves - the memoires from Siberia that have been published in abundance, eagerly bring up such images, also occasionally amplified and using the black-and-white contrast. However, this is understandable: we are dealing with a symbol that is confirmed in people's memories and thus continues to strengthen further on. In the above case, the symbol of Siberia is negative.

But this symbol could also be positive; for example, for those who were born and bred in Siberia and for whom Siberia is a homeland, that is, for Siberians.

A symbol is a product of historical experience. Juri Lotman (1999: 223) has labelled symbols as mechanisms of memory, as ties between different cultural cross sections. Especially the temporal dimension enables us to understand quite a few symbols connected to Siberia. In what follows, I will examine different aspects of the image of Siberia and attempt to show how these have emerged and what kind of meaning they convey.

An image is often shaped by stereotypes and prejudices, both of which tend to be enduring. A prejudice is a general attitude about people, groups, or phenomena, and does not succumb to change easily, even if faced with new and contradicting experience. It is a moral judgment with an emotional tinge. The information that supports the prejudice is often incomplete, tilted or erroneous. So, too, is a stereotype, an emotional positive or negative image of a person or a group, an event or a phenomenon. It is fixed and persistent in time as well as resistant to change resulting from new information. The function of a prejudice is to mediate norms and value judgments (which are often seen as universally accepted), whereas stereotypes are used to help a person to navigate in his or her surroundings and communicate with it ${ }^{1}$ (Matthes 1981: 23).

Stereotypes have an important generalisation function and meaning in human communication. Stereotypical concepts about others are a part of collective knowledge; they are acquired in the socialisation process, are regularly confirmed by their constant use in everyday and media discourses, and are used as arguments. Stereotypes reinforce some characteristics of reality whereas others are diminished (Cyrus 2001: 165; Burke 2001: 125). 
Since symbols are connected to stereotypes, we also have to analyse the stereotypes of Siberia when talking about its symbols.

In the following I will show in which way the symbols and stereotypes of Siberia are products of a historical process and as such have various starting points and sources. What happens when different stereotypes with different origins start to shape the image of Siberia? This paper aims to bring out the heterogeneity and controversy of the image of Siberia. I mainly concentrate on the symbols and stereotypes of Siberia in Estonia, but as these symbols and stereotypes have partly been borrowed from elsewhere, I also briefly describe the international background of those stereotypes. Since the main source for the stereotypes of Siberia for Estonians is direct contacts with Siberia, I will mainly concentrate on this. The deportations of the Estonian offenders to Siberia in the 19 th century, the voluntary agrarian migration in the 19th and the beginning of the 20th centuries, and the mass deportations of the Stalin era in the middle of the 20th century have influenced the formation of Estonians' stereotypes of Siberia in different ways. As sources, I have used Estonian printed media from the second half of the 19th and the 20th centuries, first and foremost printed press. From the earlier period, I have also used the Baltic-German travel literature, in which the main symbols and stereotypes of Siberia are reproduced. As a comparison, I also use the interviews conducted with the Siberian-born Estonians, which I collected during several expeditions to Siberia in the past 15 years.

\section{SIBERIA AS A LAND OF DEPORTATIONS}

For Estonians, the image of Siberia has largely been influenced by both historical events and writings about them. First I will look into how Siberia was portrayed in the 19th and beginning of the 20th centuries. Gustav Blumberg, the author of the first Estonian country studies textbook, writes at the end of the third quarter of the 19th century: “...every child knows that criminals are sent to Siberia” (Blumberg 1874: 89). The quote convincingly demonstrates that Siberia's negative image as a destination for deportations must have been general knowledge. And so it was. In fact, this was the case even considerably earlier.

At the beginning of the elaborate travelogue that Joachim Christoph Friedrich Schultz published anonymously under the name of "a Livonian", there is a list of places that the reader should not visit. Schultz writes that in France there is the threat of the guillotine, in Spain the peril of bandits, and about Siberia he writes that only people who are forced to go there, really do (Schultz 
1795/96: II-III). Where does the image of Siberia as a prison of forced labour originate from?

At first, Siberia was not the only destination of deportations in Russia: people were sent to several other less populated regions of the country. However, at the end of the 17th century, Siberia became the main destination. A Russian regulation from 1753 allowed substituting capital punishment with deportation. After that, the number of people deported to Siberia amounted to 10,000 a year at times (Spiridonova 1999: 7; Kaczýnska 1994: 13; Thomas 1982: 25-27; Lincoln 1996: 213). In the 19th century the population of Siberia grew considerably due to deportations. During the reign of Alexander I, 2000-3000 deported civilians arrived in Siberia a year, but in the middle of the 19th century the number was already up to 19,000 (Lincoln 1996: 192; Watrous 1993: 115; Wood 1991a: 10-11).

From the statistics on deportations in the 19th century, drawn up by A. D. Margolis, we learn that during $1807-1881$, 635,319 people were sent to Siberia, and this tendency was steadily increasing: in the years $1812-1821$ it was 39,761 people, in 1822-1831 - 91,709 people, in 1832-1841 - 78,823 people, in 1842-1851 62,495 people, in $1852-1861$ - 70,570 people, in 1862-1871 - 123,543 people, in $1872-1881-173,039$ people; in $1882-1898-148,032$ people. The majority of the deportees were men and although many arrived together with families, most of them came on their own (Margolis 1975: 224). The Tsarist Empire used deportation to Siberia not only to send criminals out of the central regions of Russia, but also as a means to colonise the sparsely inhabited areas of Siberia.

The importance of deportations in colonising Siberia was already emphasised by the 19th century authors, starting with the leader of Siberian regionalists N. Yadrintsev (1882). Also, the Soviet authors were generally of the opinion that deportations played a significant role in developing the Russian population in Siberia (see Kolesnikov 1975: 38).

The fact that Siberia was used as a destination for deportation created a negative image of the region in the eyes of European Russia and the rest of the world.

When Alexandr Salomon, the director of the Main Prison Administration of Russia in the years 1896-1900 called Siberia "a vast roofless prison", he used an old stereotype. When American journalist George Kennan and artist George A. Frost came to Russia in 1884 as recruitees of the New York "Century Magazine", they could not imagine the difficulties ahead of them. "One does not travel to Siberia for fun," a police officer in Perm who had studied their backgrounds told them. Soon after Kennan had come into contact with prisoners sent there and other deportees in Siberia, he understood these words perfectly well. Kennan's travel book that he published as a sequence in the "Century 
Magazine" - and later also as a book - and in which he paid attention to the situation in the Siberian prisons (Kennan n.d.), shocked the world and deepened the negative image of Siberian prisons in many countries even further.

Estonians were also sent to Siberia. It is likely that the first Estonians reached there already during the 17th century as prisoners of war (Jürgenson 2006: 28); however, this can be thought of as an isolated case that did not receive wider attention in Estonia. The 19th century deportations are a different story altogether. Relying on court documents, historian Aadu Must has pointed out a large number of cases when Estonian peasants were sent to Siberia as punishment for crimes they had committed (Must 2012: 188ff.).

Several Estonian villages in Siberia have come to existence as settlements of the deportees: Verkhnii (Upper) Suetuk in 1850, and Verkhnaia (Upper) Bulanka and Revel (Viru village) in 1861. Both in the 19th century and at the beginning of the 20th century, pastors and schoolteachers from these villages sent tens of overviews to Estonian newspapers, deepening the image of Siberia as a destination for deportations.

At the end of the 19th and beginning of the 20th centuries many writings were published in Estonia, which depicted deportation to Siberia as an act of state-inflicted violence and the deportees as victims. For instance, in the novels and short stories of several Estonian leftist writers the protagonists' crimes and subsequent deportation to Siberia were explained by social injustice and the deportees were depicted with sympathy (Mihkelson 1906; Vilde 1896, 1924). However, it is important to add that among the people sent to Siberia there were also real criminals and recidivists.

We can talk about Siberia as an important factor in the state governmental system, i.e., it was the government with its sanction mechanisms that formed a negative image of Siberia. But one has to take into account the fact that when Russia sent its criminals to Siberia, this spared the European part of Russia and its inhabitants, but created problems in Siberia.

A serious problem was vagabondage: across the whole Siberia no more than $45 \%$ of the deportees stayed in the villages that they were assigned to. At the end of the 19th century, the percentage of the escaped people who had been deported to Siberia, according to different authors, amounted to 30,000-40,000 (Wood 1991c: 123-124; Kaczýnska 1994: 123-125); these were people who, with their criminal activity, spread fear among local villagers and contributed to the fact that its negative image deepened also outside Siberia. 


\section{THE DEPICTIONS OF SIBERIA AS A LAND OF DEPORTATIONS IN THE 19TH- AND 20TH-CENTURY ESTONIAN WRITTEN WORD}

In the second half of the 19th and beginning of the 20th centuries, several writings were published in the Estonian press about the stereotype of Siberians and Siberian Estonians as criminals. It does not always become evident from the texts whether the authors of these writings have in mind a Siberian in general, i.e., a Russian-speaking Siberian, or they mean the Estonians in Siberia. With some texts, however, it is clear that an inhabitant of Siberia in general has been meant.

"The inhabitants of the Siberian taiga have run together from all four winds and they are willing to break each other to get ahead in life," said an article in the newspaper Postimees in 1900 (Postimees 1900: 1-2). R. Lipp, who served in Altai as assistant forester, writes about the Siberian peasants with dull spirit and phlegmatic temper, who can only be weaned from crime by catching them in the act and informing them in a physical manner about how it is forbidden to covet the property of others (Lipp 1939: 6). At times Siberians are depicted as people with degenerate morals, all of which is related back to the image of Siberia as a destination for deportations: the biggest criminals were sent to Siberia (Olevik 1894: 829). A letter sent from Siberia reads: "If there is but a spark of reason from the homeland left in a person's heart, then it must, in one way or another, wither in the prisons" (Sakala 1894b: 3). In another letter there is a story of how a local brewer had cheated a person [probably an emigrant] in financial matters. The settler who penned the letter adds: "No wonder, in Siberia everybody is like that, graduates of the university of evil and thus plenty smart for cheating" (Walgus 1885: 2).

In the literature from the end of the 19th and beginning of the 20th centuries, similar stereotypical images were also ascribed to the Estonians who inhabited Siberia. Georg Eduard Luiga, who at the end of the 19th century worked as a schoolteacher in a village of Estonian deportees for a few years, named his collection of short stories about Siberia in a very telling way - Wägiawallamaal (In the Land of Violence) (Luiga 1912) - and here violence meant not only the state's violence against the people deported to Siberia. This title is also an expression of the author's proposition that these deportees continued to be violent themselves.

Deportations have also added some colour to the image of Siberia. Therefore, it may sound as a surprise that in reality the percentage of the deportees in the population of Siberia has never been very high. In 1662, that is, 80 years after the beginning of the conquest of Siberia, there were 70,000 males registered in Siberia, out of whom 7400 , or $10.5 \%$, were deportees. In the middle of the 19th 
century, the deportees formed 10-11\% of the population of Siberia (Wein 1999: 55). Later on, this percentage started to fall, so that by 1897 the percentage of the deportees in Siberian population was $5.2 \%$ or $5,760,000$ people (Wood 1991b: 118). But by that time the stereotype of Siberia as a land of criminals had established itself strongly in the rest of the world.

After the First World War, Estonia became an independent country and deportation to Siberia was no longer a threat, but still the region's image endured in popular memory and writings. In 1932 the newspaper Postimees published a piece about the difficult life of ditch diggers and titled it metaphorically: The 'Siberia' of Volunteers: About the Loggers and Ditch Diggers of Alutaguse (Postimees 1932: 4).

Also during the Soviet period the use of Siberia as a prison was continued. From the 1930s until his death in 1953, Stalin sent political prisoners to the Siberian mines, where they usually stayed until their death. And probably the finishing touch to the negative image of Siberia was given by the mass deportations that started with the Chinese and Koreans from around Vladivostok during the second half of the 1930s, deportations to Siberia of Volga Germans and several Caucasus peoples in the 1940s, and mass deportations from the Baltic states in the same decade (see Jürgenson 2008: 191ff.).

The most extensive deportations in Estonia took place in 1941 and 1949. As memory researchers have pointed out, in Estonians' collective memory the different mass deportations have fused into a single big martyrdom. The meaning of the event is accepted while the details are not brought to the fore, but remain in the background (Kõresaar 2005: 104).

Previously mainly in Estonian exile communities in Western countries (Kaup 1963; Kopperman 1972; Rävälä 1981) but recently also on this side of the Baltics (Kiik 1988; Viitar 1990; Veisserik 1995; Silliksaar 2001; Hinrikus 1999; Õiger 2011) there have been numerous publications of memoirs and fictionalised writings of the deportees, which strengthen the connection of Siberia to injustice, terror and violence.

Aili Viitar, a former deportee, describes the reactions of the ones deported from Estonia:

Without any court, without giving legal proof of guilt, one is arrested from one's sleep and deported. Where? Even that we were not told. To Siberia, this was what we ourselves worked out. Where else? Since primeval times, Russia has deported its convicts to the cold country. Truly, they would not want to take us to the Crimea for a holiday! (Viitar 1990: 13) 
These examples should prove that one of the most important aspects of the image of Siberia is its long-term use as a destination for deportations. Siberia has become a frightening place where one will not go voluntarily.

Several years ago a children's summer camp programme was started between the Siberian Estonian community and home Estonia. Initially it was intended as an exchange programme, but in reality it has meant that only Siberian Estonian children come to Estonia for a summer camp: in Estonia it is difficult to find parents who would voluntarily like to send their children to Siberia.

The "demonisation" of Siberia is also expressed by deliberately absurd newspaper titles: "Voluntarily to Siberia" (Ranne 2000); "Voluntarily in Siberia" (Saarmaa 2000). During the Soviet period, north-east Estonia was referred to as Estonian Siberia because initially prisoners of war laboured there to rebuild areas destroyed by the war (Pae 2012: 36). This nickname also gives evidence of Siberia's rooted outstandingly negative image due to using Siberia as a destination for deportations.

\section{THE NATURE OF SIBERIA AND ITS DEPICTIONS}

Two years ago, when a cold front moved across Central Europe, there was the following headline in an Austrian newspaper, reading: "Wetter: Sibirien lässt grüßen” (Weather: Siberia Sends Its Greetings) (Kurier 2012). Thus, Siberia reached Europe, let the thermometers drop extraordinarily low, stalled car engines and covered lakes and rivers with ice. Siberia has become a symbol for a cold place - and that already long before one started to record cold records in the world. Of course, in terms of this, Siberia undoubtedly takes the first prize: the lowest temperatures in Siberia have been measured in Oimyakon, the world's pole of cold (outside of Antarctic), where the thermometer has indicated -71 degrees Celsius (French 1989: 1; Mote 1998: 3).

Freezing cold, but also wilderness and impenetrable forests have been part of Siberian image throughout centuries. These characteristics have emerged due to travellers and travel literature. Already the travellers from Western Europe, who, from the 18 th century onwards, increasingly travelled to Siberia and recorded their observations, emphasised the cold climate of Siberia. J. Dundas Cochrane (1825: 5) describes how axes break and how iron sticks if you touch it with a bare hand in the Siberian frost. O. Finsch writes with despair about the clothes that he had taken along from home. These clothes could be appropriate in German cold weather but not in Siberia. Despite his woolly clothes, a double waistcoat, hunter coat and furs, he was freezing in the Siberian frost, despite the fact that it was already April and spring had set in (Finsch 1879: 32-33). 
In Estonia Siberia also symbolised cold. The newspaper Perno Postimees wrote in the freezing winter of 1864: "The cold grows stronger every day; it is almost proper Siberian cold" (Perno Postimees 1864: 37). The Estonian reader got an idea of Siberian cold winters from school textbooks (Lebedev 1892: 42-43), but in the 19th century this information was increasingly drawn from the press, where cold often served as an epithet for Siberia. Siberia was the cold land (J. L. 1897: 1; Nigol 1918: 40), the land of harsh climate (Postimees 1897: 1), the harsh cold land (Olevik 1897). Cold snowy winters is a subject that added weight to the articles about Siberia, confirming the customary image of Siberia. The snowiness of Siberian winters is described by Meinhard Mühlenberg, a schoolteacher in an Estonian settlement in Western Siberia: "Instead of buildings you can see huge snowdrifts with smoky-black openings, which show that people live in those snowdrifts" (Mühlenberg 1884: 174). The Estonian settlers in Siberia described their new homeland in the letters that they sent to Estonia. Some of these letters were published in Estonian newspapers. The settlers wrote about severe winter storms, the burans, as well as the ground that was frozen to the depth of up to ten feet, and the crevices in it (H. Kr. 1915: 2). Also, the comparisons with Estonian climate had a significant importance. The settlers wrote that in Siberia winters were colder than in Estonia, without being damp (Lukk 1908: 3).

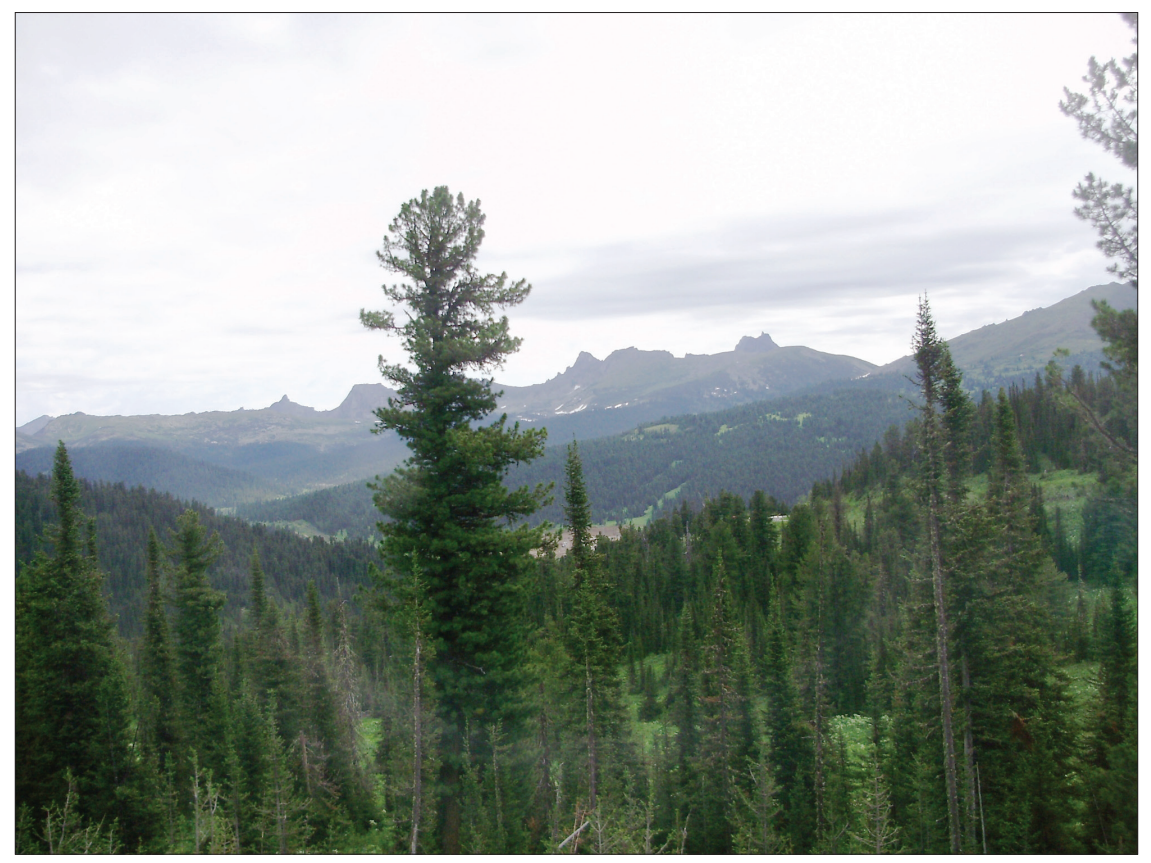

Figure 1. Taiga in Siberia. Photograph by Aivar Jürgenson 2010. 
Siberia is cold, but it is also wild. The clichés about Siberia used in the texts reflect this aspect of the image of Siberia to the extent that Siberia and the forest are inseparable. Siberian forest is a metaphor and a concept with a definite meaning, just like a bottomless hole swallowing Estonians forever. Siberian forests really seemed like another world to the settlers, like something inhuman and strange. "Here in a parish you can find such a primeval forest - the taiga - which no one has ever entered" (Postimees 1899: 2).

The impenetrable forests on the one hand and the vastness of the territory on the other are images that often stand side by side, providing a double description of the novel conditions in Siberia. The boundlessness of Siberia gives it a tingle of gloom: "Thus our brothers and sisters are lost just like behind the clouds and under the ground" (Sakala 1894a: 3-4).

Siberia's forest metaphor has a double meaning. On the one hand, there are writings on how volunteer Estonian settlers established a home for themselves by creating fields "of the Siberian forest by toiling that has become dear" (Asutawa Kogu protokoll nr. 13: 476), or in a mythological sense brought culture out of chaos. Here the forest symbolises the Great Opposer as a force of nature: the binary opposition is created by culture and nature. However, when somebody writes about Estonian deportees struggling in Siberian forests as Stalin's slaves (Väinjärve 1942: 31), then the symbol of the Siberian forest supports not only the natural aspect but also the political-historical one.

An essential part of the image of Siberia is also the image of a Siberian. Just like wilderness and enormous size are important components of the Siberian image, an inhabitant of Siberia is also wild and big. Climate-theoretical accounts on the impact of Siberian natural environment on the character and physical attributes of its inhabitants can be found in the treatments by Siberian 19thcentury regionalist literati (Jadrinzew 1886: 62; see also Anisimov 1999: 21ff.), but also from contemporary Siberian writers (Andyusev 1996, 1997; Rasputin 1987: 135-136). According to them, the Siberian inhabitant is forceful and crude, sometimes a wild person with a broad spirit and a sense of closeness to nature. Just as Siberia itself is vast and wild, so is the Siberian.

The Estonians who were deported to Siberia in the 1940s and came into contact with local people also described Siberians according to the earlier stereotypes. The descriptions include elements that show the Siberians as powerful and robust: "The hosts are a family of big, strong people with wide Siberian jaws" (Kivik 1996: 47). In such descriptions, the stereotypes of Siberian nature are ascribed to the people of Siberia as well.

An important aspect in the image of Siberian nature is its fauna; first and foremost, bears that have become one of Siberia's symbols. Meeting the bears, descriptions of bear hunting and introducing famous bear hunters are frequent 
motifs in Siberian travelogues (Kohn \& Andree 1876: 188; Messerschmidt 1962: 282; Bergman 1926: 195; Hultén 1926: 210). At the beginning of the 20th century, the Estonian press also published letters from Siberia about how the woods were crawling with bears and how the bears lurked around in villages (Nieländer 1909: 2). Stereotypes founded on such stories have persisted even through the later decades.

When in the autumn of 2000 an Estonian language teacher was sent to the Verkhnii (Upper) Suetuk village school in Eastern Siberia, the Estonian media covered the event extensively. One of the authors wrote how the teacher's friend expressed an opinion that, while living in Siberia, the teacher would have to learn to hunt bears (Korv 2000).

In the interviews that I carried out with Siberian Estonians, bears were a frequent topic. On the one hand, Siberian Estonians try to ridicule the image that the rest of the world has about how bears roam the streets in Siberia. On the other hand, they find ways to use the bear as a symbol embodying the wildness of Siberia as a tool for self-identification. If Siberian Estonians call themselves Siberi karu (Siberian bear), they do it with full self-consciousness (see Jürgenson 2003: 135; 2006: 148ff.), and with that they confront the rest of the world, including Estonia. This symbol is strong and suits well into the given context: although in the Estonian auto-stereotype the forest is also important (i.e., Estonians as forest people, see Hiiemäe 1997: 29; Jõgisalu 1997: 69), but a bear as an identifier is of no significance.

Associating Siberia with bears is a universal phenomenon. A headline in the Estonian newspaper Postimees, "The Siberian Bear Karelin Loves Rakhmaninov and Dostoyevsky" (Kees 2003), is expressive on several levels: the giant wrestler as an embodiment of a giant of nature or a savage in an absurd-like connection with high culture: contrasting the wild Siberia and the cultural world serves as a background to this association. The Siberian bear is a symbol that has evolved through centuries and is connected with historical semiotic processes, the identity of Siberia and Siberians (see Jürgenson 2003: 135-137).

Considering the Siberians as people close to nature is a part of the image that Siberia has been attributed by the outside world. This stereotype has been presented both by Russian and Western authors (especially in travelogues) throughout several centuries. But at the same time it is the auto-stereotype of Siberians, initially produced by the Siberian regionalist literates of the 19th century, who were trying to find in it a contradistinction with the Russians from Russia. The stereotype that was produced as a conscious contradistinction and a marker of an ethnic boundary has later been ingrained also in the inhabitants of Siberia and contributed to the formation of the local identity of Siberia. In addition, the Estonians from Siberia use this as an auto-stereotype. 


\section{SIBERIA AS A LAND OF ENDLESS POSSIBILITIES: VOLUNTARY EMIGRATION}

It may feel paradoxical, but although Siberia has been the carrier of mainly a negative wild image, for many it has also been a promised land, Elysium. While during several centuries trains with prisoners moved towards Siberia, there have always been those who have voluntarily escaped to this region, fleeing from landlords, etc. As a result of the 1650s schism, many Old Believers escaped to Siberia from persecutions. Throughout hundreds of years, artisans, traders, peasants and deserted soldiers have come to Siberia. In addition, after the abolishment of serfdom in 1861, an extensive emigration movement started in Russia, with one of the biggest waves arriving in Siberia. During the years 1896-1914, 80\% of Russian emigrants moved to Siberia (Goryushkin 1991: 140). Also from the Baltic countries a wave of emigrants reached Siberia during the last decade of the 19th and the first decade of the 20th centuries. For Estonians this was the most extensively used direction of emigration (see Kivimäe 1981: 68-69; Kulu 1997: 99). These were people who hoped to create a new future in Siberia for themselves and their offspring.

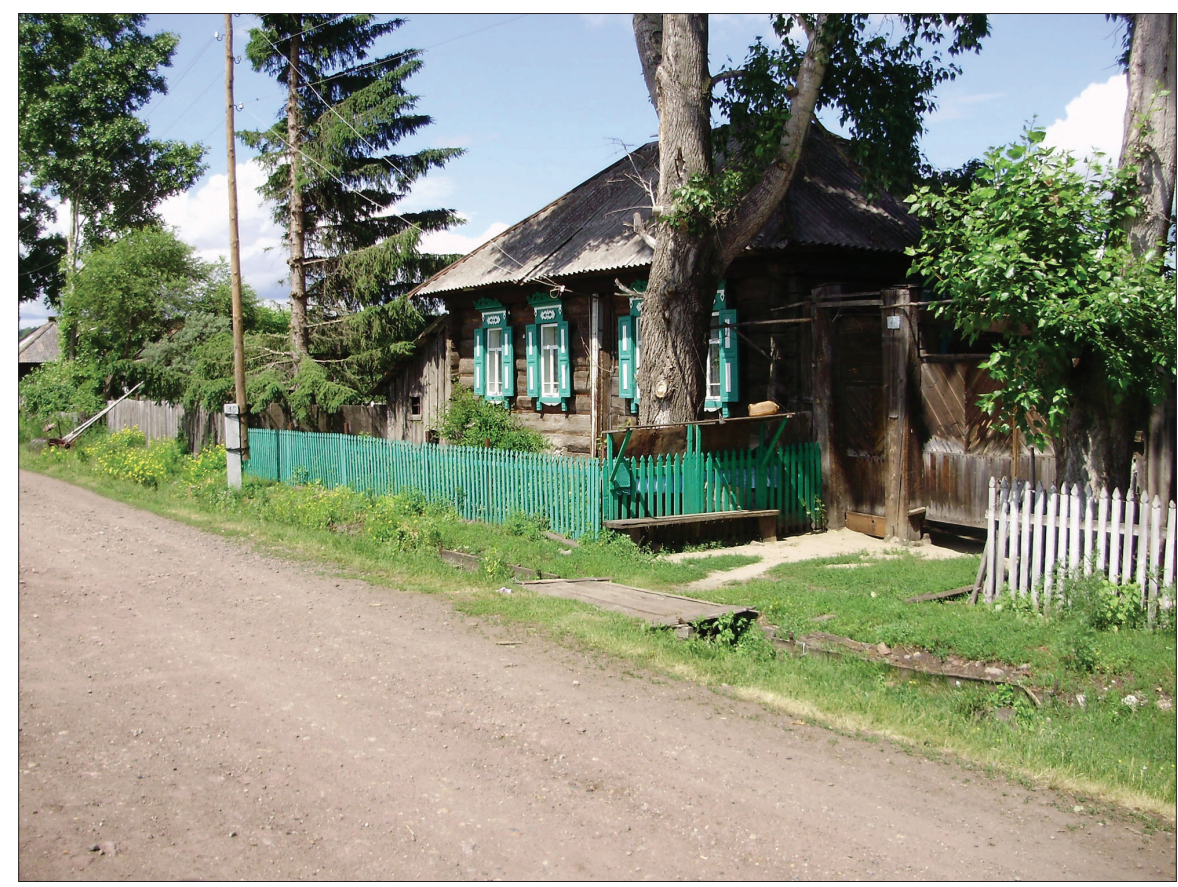

Figure 2. Estonian village Verkhnii Suetuk in Siberia. Photograph by Aivar Jürgenson 2010. 
The connection with future and freedom has given many authors who write about Siberia a good reason to associate Siberia with America, another land of future and freedom (see Petri 1886: VI; Heller 1930: 246; Snow 1977: 30; Wood 1991b: 1, 15; Lincoln 1996: 302). The basis for comparison is usually the relative newness of colonisation in both America and Siberia, and, due to that, small population, wealth of natural resources and their negligible exploitation. The authors have also compared rapidly growing cities in both America and Siberia and made observations of the mentality of people in both regions. The image of Siberia as a land of the future and its great possibilities were vastly exploited by the Estonian press at the end of the 19th and beginning of the 20th centuries. On the one hand, these were propagandistic writings, which aimed to persuade people to move to Siberia, including writings by the Estonian settlers who had already moved to Siberia and hoped to attract more compatriots to come to live with them in their settlements. Nature descriptions often reflect economic interests:

In the location of the Estonian settlement here [...] the landscape is very beautiful, the land is fertile, there are many grasslands and that is why cattle-growing is a success here. (Olevik 1893: 9)

A river rich in fish flows through our settlement. In this place the land is covered with black topsoil (chernozem) and it is fertile, if cultivated. (Olevik 1903: 274)

The countryside here is really very beautiful; especially in May and June the landscape is so wonderful that in Estonia you cannot find such even in flower gardens or manor greenhouses. Several hundreds of sorts of roses, peonies and other flowers are blooming everywhere, swaying and waving like a sea of flowers in the wind. (Sakala 1910: 2)

On the other side, the perspective of Siberia as a land of great opportunity was used in Estonian writings that served to warn people. These very same supposedly grand opportunities were ridiculed via exaggerated caricatures. For instance, the prospect of colonising Russian Far East was treated with irony:

The Yellow Sea is yellow from gold and all of the fish are by the shore. All you need is a certificate from the municipality attesting to the fact that you can hook a worm on to your fish hook. The Yellow Sea abounds in different fishes and one could even catch them with a bag [...] And the crawfish are a hundred times bigger than in the old River Raudna. One crawfish is as big as the bottom of a riddle and has a hundred chelipeds. (Postimees 1904: 2) 
The Estonian press reminded people to be careful and not to rush into the unknown, but these instances of irony also provide evidence of the fact that the peasant who left the homeland did so mainly due to economically pragmatic goals and bright hopes for the future.

The image of Siberia as a land of great opportunity has survived all the way through the 20th century until today. The offspring of original Estonian settlers still reflected on this in the interviews that I conducted with them (Jürgenson 2006: 119-120). Siberia is depicted first and foremost as a fruitful land where hard-working people can prosper. Both associating Siberia with the wild nature and the image of Siberia as a land of future have helped to strengthen Siberian regional identity.

\section{SIBERIA: A PLACE AS A CULTURAL CONSTRUCTION}

Siberia is a cultural construction: a location of not only ideas, but of embodied practices that shape identities. The understanding of space and place is created through social relations. Place is a particular articulation of social relations, a particular moment in those networks of social relations and understanding. It is clear that for those two groups - voluntary emigrants of the 19th century and the deportees of the middle of the 20th century - Siberia symbolises completely different things. No wonder that for the forcibly deported ones, the land usually remained strange, no wonder that most of the deportees returned to their homeland after they had been granted amnesty. The ones for whom Siberia was a home, assess the region and its components in a positive light. This could be exemplified by how different people with different backgrounds see Siberia, including its nature. It is clear that nature is a reflection of social and cultural experiences: when describing nature, it becomes obvious what kind of "glasses" someone wears, i.e., what is their favourite reference framework like, in which they place the symbolic objects or the landscape.

The following is a description of the homeland's nature by a woman who is a descendant of voluntary settlers:

Even that fog, when it starts emerging from the mountains - well, that I like very much. You as if step into milk - or, I cannot even say, this is so fantastically nice and beautiful. And those little flowers, how they grow there [...] And the mountains! And the strawberries that are there! (Jürgenson 2006: 162)

A deportee from Estonia, who was taken to Siberia in 1941, writes:

When the scary size of the mountain range and sulky strictness was followed by colourless wetlands and lowlands plagued by water with its 
clay huts and undisguised poverty, then we all knew that it was Asia and Siberia that was surrounding us now over there... (Kaup 1963: 30)

Yes, Siberia was strange, far away, cold and hostile, and had the impression of the land of the dead for the deportees. Sacral topography described this land as becomes obvious from the extract - as a land on the other side, i.e., as hell. This cliché had developed already earlier, under the influence of the prison camps during the tsarist period in Russia (see Grant 1993: 229), and now it acquired a deeper meaning. From the same author comes also the following vignette with a negative power of suggestion:

Dreary forests that reached the waterside, at times to the brinks, scared us. The jet-black shadows of the forest made us timid the same way as the merciless fists of the death that was waiting for us right behind the next bend of the river. (Kaup 1963: 48)

It is clear that these two descriptions stem from different positions. For both of them, Siberia has a symbolic meaning, but these meanings are different. It may feel as if the word Siberia lives its independent life and feeds on the employed stereotypes. At least for a whole century, this contradiction has characterised the image of Siberia and the reception stemming from this.

During the past century, Siberia presented at least two faces: one of them looked into the past and saw chains and barbed wire, while the other looked into the future and saw swaying cornfields and huge herds of cattle. This paradox is even further deepened by the fact that both forced and voluntary emigration headed mainly for southern Siberia: the villages of both the deportees and voluntary emigrants are situated side by side in the south of Siberia, where there are areas of fertile black soil and a benign climate. Also the 1940s deportations from the Baltic states took people to places with villages of voluntary emigrants: the homes of those who had, in their time, arrived in Siberia as Elysium. Siberia is too vast to be ascribed only one meaning to, and too multifaceted to be associated with only one emotion or opinion.

\section{CONCLUSION}

On the one hand, Siberia had become a country for deportations that injected fear in people, and, on the other hand, it presented an opportunity to escape from oppressive economic conditions in the European part of the Russian empire, a possibility of freedom.

For the Baltic nations Siberia mainly signifies a land of violence. The reason for it is the deportations carried out in the 1940s. But as we saw above, Siberia has also other stereotypes that have come into existence during different times 
via different ways. Together they have formed a heterogeneous and controversial image of the region.

The image of Siberia has been shaped by different historical events: deportations that took place during different periods of history (Tsarist Empire, Soviet period), the waves of voluntary migration, Siberia's natural conditions and physical parameters. The stereotypes of Siberia have been mediated differently. In this article I looked at how Siberian stereotypes have been presented and mediated through writings in Estonian, with comparative international material as well as segments from interviews with Siberian Estonians. According to the examples in this article, three main themes emerge in the image of Siberia:

1. Violent past of Siberia - the land of deportations;

2. Siberian nature - Siberia as a cold, vast and wild land;

3. Siberia as a land of future and endless possibilities.

In the 19th century Siberia was well known among Estonians as a destination for deportations. During the second half of the 19th century, Estonian newspapers published numerous writings about the deportees and their living conditions. At the end of the 19th and beginning of the 20th centuries, a socially critical dimension was added: the people who had been forcefully sent to Siberia were beginning to be portrayed as innocent victims of state-inflicted violence. This aspect in the image of Siberia grew more pronounced because of the mass deportations in the 1940s, which were carried out during the Soviet regime, and has persevered until today.

Not as clearly etched out, but still a significant stereotype of Siberia, is associated with nature: Siberia as a cold, vast and wild land. The metaphor "Siberian cold" was first introduced into Estonian press in the 1860s and has survived until today. The image of Cold Siberia has not been damaged by the fact that summers in the south of Siberia are warm enough for growing watermelons and grapes. The wildness of Siberia is connected with its nature: throughout a century writings have been published that speak about Siberian great vast forests as well as the animals that live in them. The metaphor for the Siberian forest has a double meaning: we saw that, on the one hand, it fits into the binary opposition culture versus nature; on the other hand, the forest symbol of Siberia can also contain, in addition to the natural aspect, a politicalhistorical aspect. In that case the Siberian forest is not a symbol of a natural chaos that human effort can mould into culture, but a symbol of violence inflicted by the state on its own people.

The third stereotype - Siberia as a land of infinite possibility and a land of the future - originated in the end of the 19th and beginning of the 20th centuries. This stereotype is mostly affiliated with the voluntary colonisation of Siberia that in Estonia lasted from the end of the 19th century until the First World 
War. This stereotype is on one level in conflict with the two ones described before, and is therefore not especially widespread in Estonia. A positive image of Siberia in Estonia is carried by the members of the so-called Siberian Estonian community: the children of former settlers who were born in Siberia and for whom Siberia is their homeland. For them the image of Siberia as a country of wild nature and Siberia as a land of the future form a unitary whole: both these images help to create the local identity of Siberia.

\section{ACKNOWLEDGEMENTS}

Research for this article was supported by research project SF 0130038s09 and ETF 9066.

\section{NOTE}

1 In practice it is hard to differentiate between prejudice and stereotype, which is why in social psychology these terms are used almost interchangeably (Matthes 1981: 23).

\section{REFERENCES}

Andyusev $1996=$ Andiusev, Boris. Likhoi chelovek v ledianoi pustyn'e. [An Insolent Man in Icy Desert.] Newspaper Krasnoiarskii Rabochii, Nos. 144/145, August 3, p. 9. Andyusev 1997 = Andiusev, Boris. Dosug i prazdniki sibiriakov. [Leisure and Holidays of the Siberians.] Newspaper Krasnoiarskii Rabochii, Nos. 242/243, December 20, p. 10.

Anisimov 1999 = Anisimov, K. Sibirskii oblastnicheskii roman: ot "Taizhan" k "Churaevym". [The Siberian Regionalist Novel: From "Taizhan" to "Churaev".] Filologicheskie stranitsy, No. 1, pp. 20-29.

Asutawa Kogu protokoll nr. 13. Eesti Asutaw Kogu (19. mai 1919). [Protocol No. 13 of the Constituent Assembly. Estonian Constituent Assembly (May 19, 1919)]. Available at http://www.digar.ee/arhiiv/et/raamatud/8472, last accessed on June 4, 2014.

Bergman, Sten 1926. Vulkane, Bären und Nomaden. Reisen und Erlebnisse im wilden Kamtschatka. Stuttgart: Strecker und Schröder Verlag.

Blumberg, Gustav 1874. Juhataja Kodu- ning isamaa tundmisele. [Guide to the Knowledge of Home- and Fatherland.] Tartu: H. Laakmann.

Burke, Peter 2001. Eyewitnessing: The Uses of Images as Historical Evidence. London: Reaktion Books.

Cochrane, Dundas J. 1825. Fussreise durch Russland und die sibirische Tatarey und von der chinesischen Grenze nach dem Eismeer und Kamtschatka. II Teil. Wien: Anton Strauss Verlag.

Cyrus, Norbert 2001. Stereotypen in Aktion: Die praktische Relevanz nationaler Schemata für einen polnischen Transmigranten in Berlin. In: Klaus Roth (ed.) Nach- 
barschaft: interkulturelle Beziehungen zwischen Deutschen, Polen und Tschechen. München \& Berlin: Waxmann, pp. 165-196.

Finsch, Otto 1879. Reise nach West-Sibirien im Jahre 1876. Berlin: Verlag Erich Wallroth.

French, R. A. 1989. Introduction. In: Alan Wood \& R. A. French (eds.) The Development of Siberia. People and Resources. Hount Mills \& Basingstoke \& Hampshire \& London: Macmillan, pp. 1-10.

Goryushkin, Leonid 1991. Migration, Settlement and the Rural Economy of Siberia, 1861-1914. In: Alan Wood (ed.) The History of Siberia: From Russian Conquest to Revolution. London \& New York: Routledge, pp. 140-157.

Grant, Bruce 1993. Siberia Hot and Cold: Reconstructing the Image of Siberian Indigenous Peoples. In: Galya Diment \& Yuri Slezkine (eds.) Between Heaven and Hell: The Myth of Siberia in Russian Culture. New York: St. Martin's Press, pp. 227-253.

Griffin 1987 = Griffin, Garol'd. Krai, ozhivshii pri sotsializme. [Region Coming to Life in Socialism.] In: Sergei Ostroumov (ed.) Sibir: kakoi ee vidit mir. [Siberia: How the World Sees It.] Irkutsk: Vostochno-Sibirskoe Knizhnoe Izdatel'stvo, pp. 93-102.

Heller, Otto 1930. Sibirien, ein anderes Amerika. Berlin: Neuer Deutscher Verlag.

Hiiemäe, Mall 1997. Metshaldjad ja muud üleloomulikud olendid metsas. [Forest Spirits and Other Supranatural Beings in the Forest.] In: Rein Ahas \& Hendrik Relve (eds.) Mets ja kultuur. [Forest and Culture.] Tartu: Eesti Roheline Liikumine, pp. 29-35.

Hinrikus, Rutt (comp.) 1999. Me tulime tagasi. [We Came Back.] Tartu: Eesti Kirjandusmuuseum.

H. Kr. 1915. Eesti asundusest. Loodus ja elu Siberis Omi Eesti asundustes. [About Estonian Settlement: Nature and Life in Om Estonian Settlements in Siberia.] Newspaper Tallinna Teataja, No. 172, July 31, pp. 2-3. Available at http://dea. nlib.ee/fullview.php?pid=s210732\&nid=22191\&frameset $=1$, last accessed on May 14, 2014.

Hultén, Eric 1926. Ins Innere Süd-Kamtschatkas. In: Sten Bergman (comp.) Vulkane, Bären und Nomaden. Reisen und Erlebnisse im wilden Kamtschatka. Stuttgart: Strecker und Schröder Verlag, pp. 200-232.

Jadrinzew, Nikolaj M. 1886. Sibirien: geographische, ethnographische und historische Studien. Bearbeitet von Ed. Petri. Jena: H. Costenoble.

J. L. 1897. Siberist. [From Siberia.] Newspaper Postimees, No. 222, October 3, p. 1. Available at http://dea.nlib.ee/fullview.php?pid=s917626\&nid=1058\&frameset=1, last accessed on May 14, 2014.

Jõgisalu, Harri 1997. Loodusest lastele. [About Nature to Children.] In: Rein Ahas \& Hendrik Relve (eds.) Mets ja kultuur. [Forest and Culture.] Tartu: Eesti Roheline Liikumine, pp. 65-70.

Jürgenson, Aivar 2003. Üks väikestest Eestidest: Siberi eesti sümbolid. [One of the Small Estonias: The Symbols of Siberian Estonia.] In: Aivar Jürgenson (ed.) Aeg ja Lugu: Esseid eesti kultuuriloost. [Time and the Story: Essays on Estonian Cultural History.] Tallinn: Ajaloo Instituut, pp. 129-142.

Jürgenson, Aivar 2006. Siberiga seotud: eestlased teisel pool Uuraleid. [Connected with Siberia: Estonians across the Urals.] Tallinn: Argo.

Jürgenson, Aivar 2008. Siber-vabaduse ja vangiahelate vahel. [Siberia: Between Freedom and Shackles.] Tallinn: Argo.

Kaczýnska, Elźbieta 1994. Das grösste Gefängnis der Welt: Sibirien als Strafkolonie zur Zarenzeit. Frankfurt \& New York: Campus Verlag. 
Kaup, Johannes 1963. Hauatagune Siber. Maria Jürvetson’i-Jürimäe elu-ja surmakirju ristilöödud elu maalt. [Sepulchral Siberia: Maria Jürvetson-Jürimäe's Letters from the Land of Crucified Life.] Geislingen: Industrie-Druck GmbH.

Kees, Tõnu 2003. Siberi karu Karelin armastab Rahmaninovi ja Dostojevskit. [The Siberian Bear Karelin Loves Rakhmaninov and Dostoyevsky.] Newspaper Postimees, November 1. Available at http://www.postimees.ee/1381591/siberikaru-karelin-armastab-rahmaninovi-ja-dostojevskit, last accessed on April 24, 2014.

Kennan, George n.d. Sibirien: Nach den im "Century Magazine” erschienenen Aufsätzen. Halle: Otto Hendel Verlag.

Kiik, Heino 1988. Maria Siberimaal. [Maria in Siberia.] Tallinn: Eesti Raamat.

Kivik, Uno 1996. Isast ja meie perekonna ärasaatmisest 14. juunil, 1941. [About Father and the Deportation of Our Family.] Siberilood: Eestlaste siberiteekond ja selle järelkajad 1940-1996. [Siberian Stories: The Way to Siberia and its Reflections in 1940-1996.] Manuscript at the National Library in Tallinn, pp. 39-71.

Kivimäe, Sirje 1981. Eesti talurahva ümberasumine 20. sajandi algul. [The Migration of Estonian Peasantry at the Beginning of the 20th Century.] In: Enn Tarvel (ed.) Eesti ajaloo probleeme. [Problems of Estonian History.] Tallinn: Eesti NSV Teaduste Akadeemia Ajaloo Instituut, pp. 66-75.

Kohn, Albin \& Andree, Richard 1876. Das Neue Buch der Reisen und Entdeckungen: Sibirien und das Amurgebiet. Leipzig: Verlag von Otto Spamer.

Kolesnikov 1975 = Kolesnikov, Aleksandr. Ssylka i zaselenie Sibiri. [Banishment and Resettlement in Siberia.] In: Leonid Goriushkin (ed.) Ssylka i katorga v Sibiri (XVIII-nachalo XX v.) [Deportation and Forced Labour in Siberia (18th Beginning of the 20th Century).] Novosibirsk: Nauka, pp. 38-58.

Kopperman, Maria 1972. Minu 12 aastat Siberis. [My 12 Years in Siberia.] Stockholm: Harta Förlag AB.

Kõresaar, Ene 2005. Elu ideoloogiad: Kollektiivne mälu ja autobiograafiline minevikutõlgendus eestlaste elulugudes. [Ideologies of Life: Collective Memory and Autobiographical Meaning-Making of the Past in Estonian Life Stories.] Tartu: Eesti Rahva Muuseum.

Korv, Neeme 2000. Filoloog Piret Toomet valmistub ajas rändama. [Philologist Piret Toomet is Getting Ready to Travel in Time.] Newspaper Postimees, August 14, p. 24.

Kulu, Hill 1997. Eestlaste tagasiränne 1940-1989: Lääne-Siberist pärit eestlaste näitel. [Estonian Return Migration 1940-1989: A Case of West-Siberian Estonians.] Tartu: Tartu Ülikooli Kirjastus.

Kurier 2012 = Wetter: Sibirien lässt grüßen. Kurier, January 29. Available at http:// kurier.at/politik/wetter-sibirien-laesst-gruessen/756.344, last accessed on April 25, 2014.

Lebedev, E. A. 1982. Geograhwi õpetus walla koolidele. [Geography Textbook for Parish Schools.] Transl. by Jaan Jung. Tartu: n.p. Available at http://www.digar.ee/ arhiiv/et/raamatud/72476, last accessed on April 25, 2014.

Lincoln, Bruce W. 1996. Die Eroberung Sibiriens. München \& Zürich: Piper Verlag.

Lipp, R. 1939. Metsavargad. [Forest Thieves.] Newspaper Päevaleht, No. 182, July 9, p. 4. Available at http://dea.nlib.ee/fullview.php?pid=s224169\&nid=108432\&fra meset=1, last accessed on May 14, 2014. 
Lotman, Juri 1999. Semiosfäärist. [On the Semiosphere.] Tallinn: Vagabund.

Luiga, Georg Eduard 1912. Wägiwallamaal. [In the Land of Violence.] Tallinn: J. Ploompuu.

Lukk, Peeter 1908. Siberist. [From Siberia.] Newspaper Elu, No. 129, June 12, p. 3. Available at http://dea.nlib.ee/fullview.php?pid=s288640\&nid=6155\&frameset=1, last accessed on May 14, 2014.

Margolis 1975 = Margolis, Aleksandr 1975. O chislennosti i razmeshchenii ssylnykh v Sibiri v kontse XIX v. [On the Number and Distribution of Deportees in Siberia at the End of the 19th Century.] In: Leonid Goriushkin (ed.) Ssylka i katorga $v$ Sibiri (XVIII - nachalo XX v.) [Deportation and Forced Labour in Siberia (18th Beginning of the 20th Century).] Novosibirsk: Nauka, pp. 223-237.

Matthes, Eckhard 1981. Das Veränderte Russland: Studien zum deutschen Russlandverständnis im 18. Jahrhundert zwischen 1725 und 1762. Frankfurt am Main \& Bern: Verlag Peter D. Lang GmbH.

Messerschmidt, Daniel G. 1962. Forschungsreise durch Sibirien 1720-1727. Edited by E. Winter \& N. A. Figurovskij, Part 1. Berlin: Akademie Verlag.

Mihkelson [Tuglas], Friedebert 1906. Hingemaa. [Soul's Acre.] Tartu: Noor-Eesti Kirjastus.

Mote, Victor L. 1998. Siberia: Worlds Apart. Colorado \& Oxford: Westview Press.

Mowat 1987 = Mouet, Farli. Polet v neizvestnost'. [A Flight to Obscurity.] In: Sergei Ostroumov (ed.) Sibir: kakoi ee vidit mir. [Siberia: How the World Sees It.] Irkutsk: Vostochno-Sibirskoe Knizhnoe Izdatel'stvo, pp. 65-93.

Mühlenberg, Meinhard 1884. Lääne-Siberist. [From Western Siberia.] Newspaper Kündja, No. 15, April 11, pp. 175-176. Available at http://dea.nlib.ee/fullview. php?pid=s329498\&nid=28331\&frameset=1, last accessed on May 14, 2014.

Must, Aadu 2012. Siber ja Eesti. Jalaraua kõlin. [Siberia and Estonia: Clink of the Fetters.] Tartu: Tartu Ülikooli Kirjastus.

Nieländer, S. 1909. Kiri Siberist I. [A Letter from Siberia I.] Newspaper Rahva Päevaleht, No. 27, February 5 (18), p. 2.

Nigol, August 1918. Eestlaste asundused ja asupaigad Wenemaal. [Estonian Settlements in Russia.] Tartu: Eesti Kirjanduse Seltsi Kodumaa Tundmaõppimise Toimkond. Available at http://ida.aule.ee/raamatud/nigol1918_orig.pdf, last accessed on April 28, 2014.

Õiger, Karl 2011. Ma tulin tagasi. [I Came Back.] Tallinn: Printon.

Olevik 1893 = Siberis. [In Siberia.] Newspaper Olevik, No. 1, January 4, pp. 9-10. Available at http://dea.nlib.ee/fullview.php?pid=s385653\&nid=112344\&frames et=1, last accessed on May 14, 2014.

Olevik 1894 = Sõnumed. [News.] Newspaper Olevik, No. 39, September 26, pp. 828-829. Available at http://dea.nlib.ee/fullview.php?pid=s377010\&nid=112736\&frames et=1, last accessed on May 14, 2104.

Olevik 1897 = Teated. [News.] Newspaper Olevik, No. 40, October 7, pp. 894-895. Available at http://dea.nlib.ee/fullview.php?pid=s376268\&nid=113293\&frames et=1, last accessed on June 5, 2014.

Olevik 1903 = Eesti asunikkude elust. [On the Life of Estonians Settlers.] Newspaper Olevik, No. 12, March 25, p. 274. Available at http://dea.nlib.ee/fullview.php?pi $\mathrm{d}=\mathrm{s} 375996 \&$ nid $=118451 \&$ frameset=1, last accessed on May 14, 2014. 
Pae, Taavi 2012. Võrdnimed Eestis. [Toponyms in Estonian.] In: Jüri Metsalu (ed.) Pärimus inimese ja maastiku dialoogis. Ettekannete teesid. [Tradition in Man-Landscape Dialogue. Abstracts.] Tartu: Eesti Kirjandusmuuseumi Teaduskirjastus, pp. 3537. Available at http://www.folklore.ee/era/tk2012/TK12teesid.pdf, last accessed on April 28, 2014.

Parts, Heiki 1954. Nädalalõpumatk Colorado kanjonile. [A Weekend Trip to Colorado Canyon.] Journal Kodukolle, No. 9, pp. 9-10.

Perno Postimees 1864 = Newspaper Perno Postimees, No. 5, January 29, p. 37. Available at http://dea.nlib.ee/fullview.php?pid=s385923\&nid=10176\&frameset=1, last accessed on May 14, 2014.

Petri, Eduard 1886. Vorwort. In: Sibirien: geographische, ethnographische und historische Studien von N. Jadrinzew. Bearbeitet von Ed. Petri. Jena: Hermann Costenoble, pp. V-XIII. Available at https://archive.org/details/sibiriengeograp00petrgoog, last accessed on April 28, 2014.

Postimees 1897 = Siberisse rännanud rahva hädakorra kergituseks. [For Alleviation of the Misery of the People Migrated to Siberia.] Newspaper Postimees, No. 223, October 4, p. 1. Available at http://dea.nlib.ee/fullview.php?pid=s912674\&nid=1 060\&frameset=1, last accessed on May 14, 2014.

Postimees 1899 = Eesti asujatest Siberis. [About Estonians Settlers in Siberia.] Newspaper Postimees, No. 144, July 6, p. 2. Available at http://dea.nlib.ee/fullview.php?pid= s268261\&nid=3665\&frameset=1, last accessed on May 14, 2104.

Postimees $1900=$ Siberisse rändamise himulistele. [To the People Who Want to Migrate to Siberia.] Newspaper Postimees, No. 93, April 26, pp. 1-2. Available at http:// dea.nlib.ee/fullview.php?pid=s246489\&nid=5230\&frameset $=1$, last accessed on May 14, 2014.

Postimees 1904 = Eesti asunikud kaugel Idas. [Estonian Settlers in Far East.] Newspaper Postimees, No. 98, May 3, pp. 1-2. Available at http://dea.nlib.ee/fullview.php?pi $\mathrm{d}=\mathrm{s} 287769 \&$ nid $=2382 \&$ frameset $=1$, last accessed on May 14, 2014.

Postimees 1932 = Vabatahtlikkude "Siber". Alutaguse metsa- ja kraavitöölistest. [The „Siberia“ of Volunteers: About the Loggers and Ditch Diggers of Alutaguse.] Newspaper Postimees, No. 278, November 26, p. 4. Available at http://dea.nlib. ee/fullview.php?pid=s228524\&nid=52324\&frameset=1, last accessed on May 14, 2014.

Ranne, Raul 2000 Vabatahtlikult Siberisse. [Voluntarily to Siberia.] Newspaper Eesti Ekspress, No. 44, November 2, p. 29.

Rasputin, Valentin 1987. Sibirien ohne Romantik. Essay. München: C. Bertelsmann Verlag.

Rävälä, Annus [Tarand, Helmut] 1981. Vorkuta värsse. [Verses from Vorkuta.] Lund: Eesti Kirjanike Kooperatiiv.

Saarmaa, Triin 2000. Vabatahtlikult Siberis. [Voluntarily in Siberia.] Journal Eesti Loodus, No. 12, pp. 519-520.

Sakala 1894a = Kirjad Siberist I. [Letters from Siberia I.] Newspaper Sakala, No. 13, March 30, pp. 3-4. Available at http://dea.nlib.ee/fullview.php?pid=s228524\&ni $\mathrm{d}=52324 \&$ frameset $=1$, last accessed on May 14, 2014 .

Sakala 1894b = Kirjad Siberist II. [Letters from Siberia II.] Newspaper Sakala, No. 15, April 13, pp. 3-4. Available at http://dea.nlib.ee/fullview.php?pid=s289756\&nid $=16993 \&$ frameset $=1$, last accessed on May 14, 2104 . 
Sakala 1910 = Eesti asunikud. [Estonian Settlers.] Newspaper Sakala, No. 11, January 29, p. 2. Available at http://dea.nlib.ee/fullview.php?pid=s910970\&nid $=20001 \&$ frameset $=1$, last accessed on May 14, 2014.

Schultz, Joachim Christoph Friedrich 1795/96. Reise eines Liefländers von Riga nach Warschau, durch Südpreußen, über Breslau, Dresden, Karlsbad, Bayreuth, Nürnberg, Regensburg, München, Salzburg, Linz, Wien und Klagenfurt, nach Botzen in Tyrol. 3 vols. Berlin: Friedrich Vieweg.

Silliksaar, Silver 2001. Sinasilmitsi Siberiga: Mälestusteraamat 1951. aasta küüditamisest. [Facing Siberia: Memories of the 1951 Deportation.] Võru: Võru Täht.

Smitt 1987 = Smitt, Emma 1987. Chto ia otkryla v Sibiri. [What I Discovered in Siberia.] In: Sergei Ostroumov (ed.) Sibir: kakoi ee vidit mir. [Siberia: How the World Sees It.] Irkutsk: Vostochno-Sibirskoe Knizhnoe Izdatel'stvo, pp. 103-124.

Snow, Russel E. 1977. The Bolsheviks in Siberia 1917-1918. Cranbury \& New Jersey: Associated University Presses, Inc.

Spiridonova 1999 = Spiridonova, G. Motif ssylki v Sibirskoi belletristike 30-kh godov XIX veka. [The Motive of Deportation in the Siberian Fiction of the 1830s.] Filologicheskie stranitsy, No. 1, pp. 6-13.

Thomas, Ludmila 1982. Geschichte Sibiriens. Von den Anfängen bis zur Gegenwart. Berlin: Akademie-Verlag.

Väinjärve 1942 = Väinjärve valla bolshevike võimu alt vabanemise ja Omakaitse Koeru Piirk.-Pataljoni aastapäeva aktuse kava. [Programme for the Ceremony to Celebrate the First Anniversary of Väinjärve Liberation from Bolsheviks and the Home Guard Battalion of Koeru Region.] Koeru: Väinjärve valla vabastamis-aastapäeva korraldav toimkond. Available at http://digar.nlib.ee/ digar/show/?id=104920, last accessed on April 28, 2014.

Veisserik, Artur 1995. Ma armastasin Eestit. [I Loved Estonia.] Tartu: Ilmamaa.

Viitar, Aili 1990. Siberi-raamat. [Book of Siberia.] Tallinn: Eesti Raamat.

Vilde, Eduard 1896. Külmale maale. [To the Cold Land.] Jurjev: Postimees.

Vilde, Eduard 1924. Mahtra sõda. [The Mahtra War.] Tallinn: Varrak.

Walgus 1885 = Siberi maalt. [From Siberia.] Newspaper Walgus, No. 22, June 8, p. 2. Available at http://dea.nlib.ee/fullview.php?pid=s189406\&nid=211517\&frames et=1, last accessed on May 14, 2014.

Watrous, Stephen 1993. The Regionalist Conception of Siberia, 1860 to 1920. In: Galya Diment \& Yuri Slezkine (eds.) Between Heaven and Hell: The Myth of Siberia in Russian Culture. New York: St. Martin's Press, pp. 113-132.

Wein, Norbert 1999. Sibirien. Gotha und Stuttgart: Klett-Perthes.

Wood, Alan 1991a. Editor's Preface. In: Alan Wood (ed.) The History of Siberia: From Russian Conquest to Revolution. London \& New York: Routledge, pp. IX-X.

Wood, Alan 1991b. Introduction: Siberia's Role in Russian History. In: Alan Wood (ed.) The History of Siberia: From Russian Conquest to Revolution. London \& New York: Routledge, pp. 1-16.

Wood, Alan 1991c. Russia's 'Wild East': Exile, Vagrancy and Crime in NineteenthCentury Siberia. In: Alan Wood (ed.) The History of Siberia: From Russian Conquest to Revolution. London \& New York: Routledge, pp. 117-137.

Yadrintsev 1882 = Iadrintsev, Nikolai. Sibir kak koloniia. [Siberia as a Colony.] SanktPeterburg: Tipografiia M. M. Stasiulevicha. 